\title{
The Electron Transport System of an Extremely Thermophilic Bacterium
}

\author{
By CHRISTOPHER W. HICKEY AND R. M. DANIEL \\ School of Science, University of Waikato, Hamilton, New Zealand
}

(Received 1 February 1979)

\begin{abstract}
Active, membrane-bound NADH and succinate oxidase activities with a temperature optimum of $75^{\circ} \mathrm{C}$ were demonstrated in an extremely thermophilic bacterium. These were relatively stable in cell-free extracts and respiratory particles at $75^{\circ} \mathrm{C}$, but at $90{ }^{\circ} \mathrm{C}$ the half-lives of these oxidase systems were about $15 \mathrm{~min}$ in respiratory particles and $80 \mathrm{~min}$ in cell-free extracts. The stability of the NADH oxidase in respiratory particles at $90{ }^{\circ} \mathrm{C}$ was enhanced by $2 \mathrm{M}-\left(\mathrm{NH}_{4}\right)_{2} \mathrm{SO}_{4}, 50 \%$ (v/v) glycerol and by NADH. A number of other substrates were oxidized by the electron transport system. Respiratory particles contained cytochromes $a-613, a-602, b-559$, cytochrome $o$ and at least one $c$-type cytochrome, $c-555$. The soluble fraction contained at least two $c$-type cytochromes, at least one of which was CO-reactive. The sensitivity of NADH and succinate oxidases to a range of inhibitors was determined.
\end{abstract}

\section{IN TRODUCTION}

Interest in micro-organisms living in extreme thermal environments has increased over the past few years (see, for example, Brock, 1967; Brock \& Brock, 1971; Williams, 1975) and a number of enzymes from extreme thermophiles have been characterized (see, for example, Campbell \& Pace, 1968; Singleton \& Amelunxen, 1973; Zuber, 1976; Ljungdahl \& Sherod, 1976). Despite interest in the membrane composition of such organisms (Ray et al., 1971 $a, b$; Jackson et al., 1973a), little is known about their electron transport systems (Pask-Hughes \& Williams, 1975; McFetters \& Ulrich, 1972). In this paper we describe the electron transport system of a thermophilic bacterium isolated from the Rotorua thermal region of New Zealand. The organism was Thermus-like (H. Morgan, personal communication) and, pending the final results of taxonomic work, it will be referred to as Thermus T351. The electron transport system (this paper) and other physiological and biochemical activities (H. Morgan \& D. A. Cowan, personal communication) displayed optimal activity between 70 and $80^{\circ} \mathrm{C}$ and negligible activity below $40^{\circ} \mathrm{C}$. The organism can therefore be described as caldoactive (Heinen \& Heinen, 1972; Williams, 1975) or extremely thermophilic.

\section{METHODS}

Organism. Thermus $\mathrm{T} 351$ was isolated from a hot pool $\left(79 \pm 4{ }^{\circ} \mathrm{C}\right)$, low in sulphide, at pH $7 \cdot 8$. The organism grew well at $75{ }^{\circ} \mathrm{C}$ at $\mathrm{pH} 7 \cdot 5$ to $7 \cdot 8$, but grew poorly below $60^{\circ} \mathrm{C}$; it was obligately aerobic. Cells were Gram-negative, non-motile, non-sporulating rods.

Maintenance and growth. Cultures were maintained on a medium consisting of Allen's salts (Jackson et al., $1973 b$ ) with $0 \cdot 1 \%(\mathrm{w} / \mathrm{v})$ yeast extract (BBL) and $0 \cdot 1 \%(\mathrm{w} / \mathrm{v})$ trypticase $(\mathrm{BBL})$ in liquid culture at $75^{\circ} \mathrm{C}$. The medium was adjusted to $\mathrm{pH} 8 \cdot 2$ before autoclaving; the final $\mathrm{pH}$ was $7 \cdot 5$.

The organism was grown at $75{ }^{\circ} \mathrm{C}$ on a similar medium, but with $0.3 \%$ yeast extract and $0.3 \%$ trypticase. Batches of $500 \mathrm{ml}$ were grown in 21 Erlenmeyer flasks in an orbital incubator; bacteria were either harvested 
directly or used to inoculate a 201 fermenter. Bacteria were harvested during the late-exponential phase ( 10 to $12 \mathrm{~h}$ after inoculation) at an $A_{650}$ of about $1 \cdot 4$ (about $2 \cdot 5 \times 10^{7}$ cells ml $^{-1}$ ).

Preparation of subcellular fractions. Fractions were prepared as described by Daniel (1970), except that small particles were sedimented at $250000 \mathrm{~g}$ for $1 \mathrm{~h}$.

Measurement of oxidase activities. Oxygen uptake was measured polarographically using a Rank oxygen electrode (Rank Bros, Bottisham, Cambs.). The reaction mixture (total vol. $2.5 \mathrm{ml}$ ) contained $0 \cdot 1 \mathrm{M}$ $\mathrm{KH}_{2} \mathrm{PO}_{4} / \mathrm{Na}_{2} \mathrm{HPO}_{4}$ buffer, $\mathrm{pH} 7 \cdot 0$, a suitable amount of membrane particle protein and either $5 \mu \mathrm{mol}$ $\mathrm{NADH}$ or $50 \mu \mathrm{mol}$ of the other substrates. Buffers were equilibrated at the desired temperature with sparged air for $30 \mathrm{~min}$. Particles were equilibrated in the electrode for $2 \mathrm{~min}$, and oxidase activities were determined during the first minute after the addition of substrate.

Spectrophotometry. Difference spectra were obtained at room temperature with a Cary model 17 recording spectrophotometer. The concentration of individual cytochromes was determined from the dithionitereduced minus oxidized difference spectra, and for cytochrome $o$, from the reduced $+\mathrm{CO}$ minus reduced difference spectra. The following wavelength pairs and molar absorption coefficients $\left(1 \mathrm{~mol}^{-1} \mathrm{~cm}^{-1}\right)$ were used: $c$-type cytochrome, 553 and $540 \mathrm{~nm}, \epsilon=19000$ (Chance et al., 1955); total $b$-type cytochrome, 560 and $575 \mathrm{~nm}, \epsilon=17500$ (Deeb \& Hager, 1964); cytochrome $o-\mathrm{CO}, 417$ and $429 \mathrm{~nm}, \quad \epsilon=170000$ (Daniel, 1970); $a$-type cytochrome, 602 and $630 \mathrm{~nm}$ and 613 and $630 \mathrm{~nm}, \epsilon=24000$ (Van Gelder, 1966).

\section{RESULTS AND DISCUSSION}

Both NADH and succinate oxidase systems were membrane-bound (Table 1). NADH oxidase activity in respiratory particles, especially in the large particles, rose markedly on the addition of supernatant, but the succinate oxidase activity was unaffected. When large or small particles were subjected to additional washings, NADH oxidase activity decreased further. Little or no stimulation of activity was observed on adding purified $c$-type cytochromes derived from the supernatant. This suggests that the NADH dehydrogenase is only loosely attached to the cell membrane and that, as in other bacteria (e.g. Smith, 1968), the rate-limiting step in respiration is the dehydrogenase.

Washed membrane particles could oxidize other substrates, including glutamate and malate $\left[>0.05 \mu \mathrm{mol} \mathrm{O} \min ^{-1}(\mathrm{mg} \text { protein })^{-1}\right]$, and lactate, citrate, fumarate, glycerol and glucose [0.005 to $0.02 \mu \mathrm{mol} \mathrm{O}_{2} \mathrm{~min}^{-1}$ (mg protein) $\left.{ }^{-1}\right]$. Except in the case of succinate and lactate, activities were enhanced by added supernatant and by NAD, suggesting that these other dehydrogenases are NAD-linked and at least partially soluble. Acetate, sucrose, mannitol and ethanol were not oxidized.

At $75^{\circ} \mathrm{C}$, the optimum $\mathrm{pH}$ and optimum concentration of phosphate buffer for both $\mathrm{NADH}$ and succinate oxidases were $\mathrm{pH} 7 \cdot 0$ and $0 \cdot 1 \mathrm{M}$, respectively. After 2 min preincubation at temperatures between 40 and $95^{\circ} \mathrm{C}$, NADH and succinate oxidases were most active at $75^{\circ} \mathrm{C}$ in cell-free extract and in large or small particles. The NADH oxidase activity in respiratory particles was particularly temperature-sensitive, the activities at 70 and $80^{\circ} \mathrm{C}$ being about half that at $75^{\circ} \mathrm{C}$, and the activity at $40^{\circ} \mathrm{C}$ was less than one-tenth of that at $75^{\circ} \mathrm{C}$.

At $75^{\circ} \mathrm{C}$, apart from an initial partial loss of activity, the respiratory activities of unbroken bacteria, cell-free extract and respiratory particles were relatively stable, although there was a substantial short-term increase in succinate respiration of unbroken bacteria (Fig. 1). The endogenous respiration (not shown) followed a similar pattern. At $90{ }^{\circ} \mathrm{C}$, short-term increases were observed for unbroken bacteria and cell-free extracts, but not washed respiratory particles. At $90{ }^{\circ} \mathrm{C}$ the succinate oxidase of unbroken bacteria and the $\mathrm{NADH}$ oxidase of washed respiratory particles were substantially less stable than the oxidase activities of cell-free extract. A likely explanation is that the succinate transport system is thermolabile, and that cytoplasmic factors are not only able to stabilize oxidase activities in respiratory particles but are also implicated in the activation effect.

These stabilities are appreciably greater than those reported for NADH oxidase from Bacillus stearothermophilus protoplasts (Wisdom \& Welker, 1973). Pask-Hughes \& Williams (1975) reported similar thermostabilities for malate and isocitrate dehydrogenases in crude 
Table 1. Rates of oxygen uptake by fractions from starved Thermus $\mathrm{T} 351$ at $75^{\circ} \mathrm{C}$

Oxygen uptake rates were determined after $2 \mathrm{~min}$ preincubation at $75^{\circ} \mathrm{C}$ and are expressed as $\mu \mathrm{mol} \mathrm{O} \mathrm{O}_{2}$ consumed $\mathrm{min}^{-1}(\mathrm{mg} \text { protein })^{-1}$. Numbers in parentheses are rates in the presence of added supernatant (10 $\mathrm{mg}$ protein).

Rates of oxygen uptake by different cell fractions

\begin{tabular}{|c|c|c|c|c|}
\hline Substrate & $\begin{array}{c}\text { Intact } \\
\text { organisms }\end{array}$ & $\begin{array}{c}\text { Large } \\
\text { particles }\end{array}$ & $\begin{array}{c}\text { Small } \\
\text { particles }\end{array}$ & Supernatant \\
\hline Endogenous & 0.013 & $\begin{array}{c}<0.001 \\
(<0.001)\end{array}$ & $\begin{array}{c}<0.001 \\
(<0.001)\end{array}$ & $<0.001$ \\
\hline NADH & - & $\begin{array}{c}0.073 \\
(0.370)\end{array}$ & $\begin{array}{c}0 \cdot 170 \\
(0 \cdot 410)\end{array}$ & $<0.001$ \\
\hline Succinate & 0.019 & $\begin{array}{c}0 \cdot 180 \\
(0 \cdot 180)\end{array}$ & $\begin{array}{c}0 \cdot 114 \\
(0 \cdot 114)\end{array}$ & $<0.001$ \\
\hline
\end{tabular}

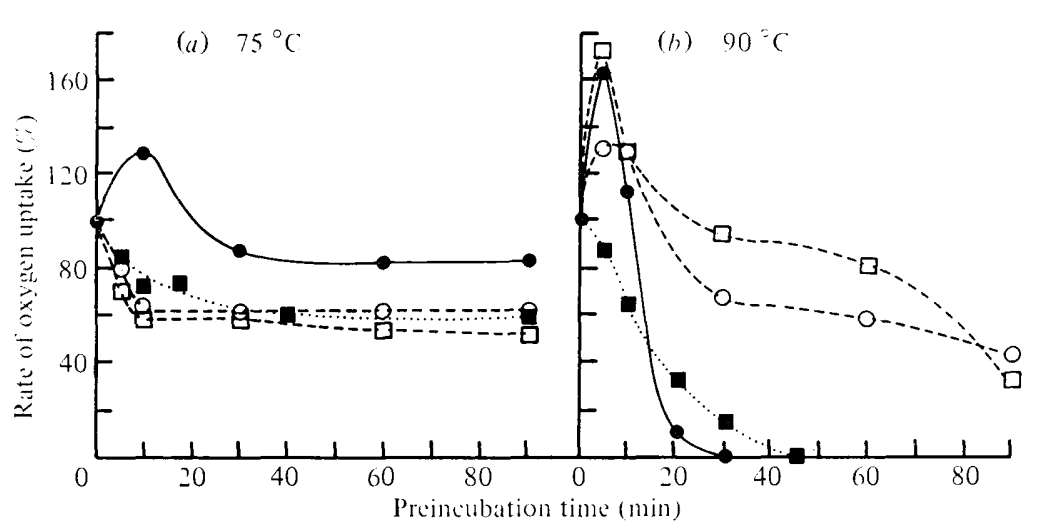

Fig. 1. Effect of preincubation at $75^{\circ} \mathrm{C}(a)$ and $90^{\circ} \mathrm{C}(b)$ on the oxidase activities of Thermus T351 suspensions and membrane particles. Assays were performed at $75^{\circ} \mathrm{C}$ as described in Methods: , succinate oxidase activity of unbroken bacteria; $O$, succinate oxidase activity of cell-free extract; $\square$, NADH oxidase activity of cell-free extract; $\square$, NADH oxidase activity of large membrane particles. Rates of oxygen uptake are expressed as a percentage of the rate without preincubation.

extracts from Thermus strains YT1, NH and DI at $90{ }^{\circ} \mathrm{C}$. An initial increase in activity of isocitrate dehydrogenase from YT1 was attributed to cold inactivation of the enzyme. We have no evidence that this is the case for the activations observed here (Fig. 1). Purified glyceraldehyde-3-phosphate dehydrogenase from Thermus aquaticus at $90{ }^{\circ} \mathrm{C}$ apparently had similar or greater thermostability (Hocking \& Harris, 1973). However, the thermostability of NADH oxidase reported here is presumably that of the least thermostable component in the electron transport system.

The thermostability of the NADH oxidase activity of respiratory particles at $90{ }^{\circ} \mathrm{C}$ over a 15 min period was unaffected by phosphate buffer concentration $(0.01$ to $2 \mathrm{M}), 1 \mathrm{M}-\mathrm{MgSO}_{4}$ or by $10 \mathrm{mg}$ casein $\mathrm{ml}^{-1}$. Stability was enhanced about twofold by $50 \%(\mathrm{v} / \mathrm{v})$ glycerol, $2 \mathrm{M}-\left(\mathrm{NH}_{4}\right)_{2} \mathrm{SO}_{4}$, and $10 \mathrm{mg} \mathrm{NADH} \mathrm{ml}{ }^{-1}$. Rates were determined at $75^{\circ} \mathrm{C}$.

The absorption peaks of $a-, b$ - and $c$-type cytochromes in washed respiratory particles were at 613 and 602,559 and $555 \mathrm{~nm}$, respectively (Fig. $2 a$ ). The major $a$-type cytochrome had an absorption peak at $613 \mathrm{~nm}$, which is unusual; the troughs at 615 and $444 \mathrm{~nm}$ in the CO spectra suggest that at least one of the $a$-type cytochromes is a terminal oxidase. The trough at $561 \mathrm{~nm}$ and the peak at $417 \mathrm{~nm}$ indicate the presence of cytochrome $o$, and the trough at $550 \mathrm{~nm}$ suggests that there was some CO-reactive $c$-type cytochrome in the respiratory particles. The soluble fraction (Fig. $2 b$ ) contained at least two soluble $c$-type 


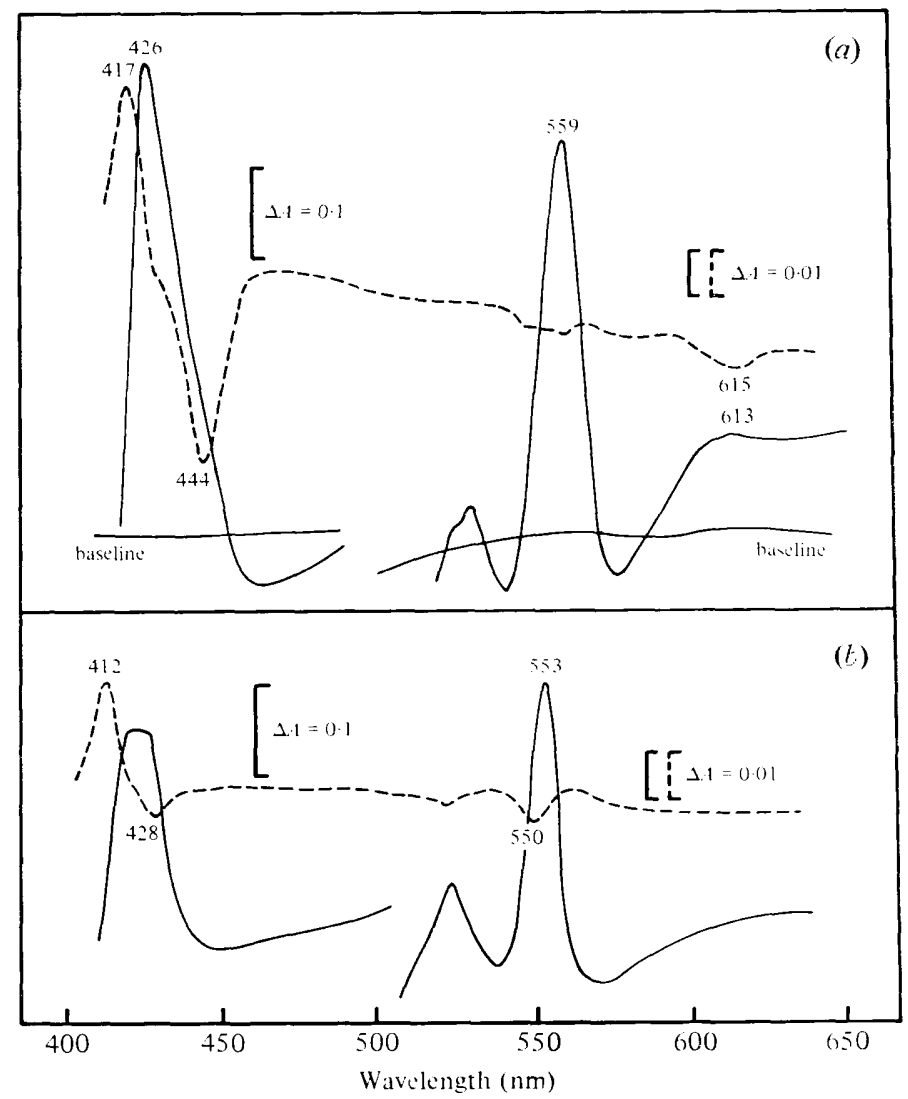

Fig. 2. Difference spectra at room temperature of $(a)$ the small membrane particle fraction $(5 \cdot 0 \mathrm{mg}$ protein $\left.\mathrm{ml}^{-1}\right)$ and $(b)$ the supernatant $\left(6.0 \mathrm{mg}\right.$ protein $\left.\mathrm{ml}^{-1}\right)$ prepared from Thermus $\mathrm{T} 351:-$ dithionite-reduced minus oxidized difference spectra; - - -, dithionite-reduced + $\mathrm{CO}$ minus dithionite-reduced difference spectra.

cytochromes, since the ratio of the peaks at 420 and $426 \mathrm{~nm}$ varied somewhat between preparations, and at least one of these was CO-reactive. $b$ - and $c$-type cytochromes in Thermus NH have been reported by Pask-Hughes \& Williams (1975), and $a-605$ and $b$ - and c-type cytochromes in a Thermus aquaticus type organism by McFetters \& Ulrich (1972).

Cytochrome concentrations $\left[\mu \mathrm{mol}\right.$ cytochrome $\left.(\mathrm{g} \text { protein })^{-1}\right]$ in respiratory particles were: $a-602,0.03 ; a-613,0.05$; total $b$-type, $0.89 ; o, 0.21$; total $c$-type, 0.64 ; and in the supernatant, 0.79 for cytochrome $c$ and 0.02 for the CO-reactive cytochrome $c$. These concentrations are similar to those found in other aerobes (Gel'man et al., 1975).

The sensitivity to respiratory inhibitors was within the range found for other bacteria (e.g. Daniel, 1970; Erickson \& Parker, 1969; Taniguchi \& Kamen, 1965) (Table 2) and there was no evidence that active sites are less exposed than in non-thermophiles. Terminal oxidase inhibitors and amytal affected NADH and succinate oxidases equally. Rotenone had more effect on the NADH oxidase activity, but bathophenanthroline, 2-heptyl-4hydroxyquinoline- $N$-oxide and antimycin A were all more effective inhibitors of succinate oxidase. Bathophenanthroline was specific for succinate oxidase at the concentrations used.

Bacterial electron transport systems vary widely in their oxidase activities, components and inhibitor sensitivities. Apart from its thermostability and the presence of an $a$-type cytochrome with an unusual absorption peak, the electron transport system of this extreme thermophile does not fall outside the range of this variation and we have no evidence that 
Table 2. Effect of inhibitors on the NADH and succinate oxidase activities of respiratory particles at $75^{\circ} \mathrm{C}$

Activities are expressed as a percentage of the uninhibited oxidase activity. Each assay contained

\begin{tabular}{|c|c|c|c|}
\hline \multirow[b]{2}{*}{ Inhibitor } & \multirow[b]{2}{*}{ Concn $(\mu \mathrm{M})$} & \multicolumn{2}{|c|}{ Activity retained $(\%)$} \\
\hline & & $\begin{array}{l}\text { NADH } \\
\text { oxidase }\end{array}$ & $\begin{array}{c}\text { Succinate } \\
\text { oxidase }\end{array}$ \\
\hline $\mathrm{KCN}$ & $\begin{array}{r}10 \\
100 \\
1000\end{array}$ & $\begin{array}{l}87 \\
56 \\
28\end{array}$ & $\begin{array}{l}80 \\
40 \\
26\end{array}$ \\
\hline $\mathrm{NaN}_{3}$ & 500 & 86 & 85 \\
\hline $\mathrm{CO} / \mathrm{O}_{2}$ & $\begin{array}{r}\left(0 \cdot 3^{*}\right) \\
\left(2 \cdot 4^{*}\right) \\
\left(14 \cdot 3^{*}\right)\end{array}$ & $\begin{array}{l}92 \\
60 \\
20\end{array}$ & $\begin{array}{l}- \\
- \\
-\end{array}$ \\
\hline Amytal & 500 & 88 & 77 \\
\hline Rotenone & 200 & 48 & 89 \\
\hline Bathophenanthroline & $\begin{array}{r}50 \\
200\end{array}$ & $\begin{array}{l}100 \\
100\end{array}$ & $\begin{array}{l}76 \\
24\end{array}$ \\
\hline $\begin{array}{l}\text { 2-Heptyl-4-hydroxyqu } \\
N \text {-oxide }\end{array}$ & 25 & 40 & 11 \\
\hline Antimycin A & 25 & 66 & 47 \\
\hline
\end{tabular}

* Concentrations of $\mathrm{CO} / \mathrm{O}_{2}$ are expressed as the molar ratio in solution.

the function of the bacterial membrane is in any way unusual. Furthermore, despite the largely hydrophobic environment of the electron transport system, its thermostability seems similar to that exhibited by soluble proteins from other extreme thermophiles.

We thank Dr H. Morgan for supplying the organism used in this work and for helpful suggestions concerning its maintenance and growth.

\section{REFERENCES}

Brock, T. D. (1967). Life at high temperatures. Science 158, 1012-1019.

Brock, T. D. \& Brock, M. L. (1971). Microbial studies of thermal habitats of the central volcanic plateau region, North Island, New Zealand. New Zealand Journal of Marine and Freshwater Research 5, 233-258.

Campbell, L. L. \& Pace, B. (1968). Physiology of growth at high temperatures. Journal of Applied Bacteriology 31, 24-35.

Chance, B., Williams, G. R., Holmes, W. F. \& Higgins, J. (1955). Respiratory enzymes in oxidative phosphorylation. V. Journal of Biological Chemistry 217, 439-451.

DANIEL, R. M. (1970). The electron transport system of Acetobacter suboxydans with particular reference to cytochrome o. Biochimica et biophysica acta 216, 328-341.

DeEb, S. S., \& HAger, L. P. (1964). Crystalline cytochrome $b_{1}$ from Escherichia coli. Journal of Biological Chemistry 239, 1024-1031.

Erickson, S. K. \& Parker, G. L. (1969). The electron-transport system of Micrococcus lutea (Sarcina lutea). Biochimica et biophysica acta 180, 56-62.
Gel'man, N. S., Lukoyanova, M. A. \& OstrovSKII, D. N. (1975). Biomembranes, vol. 6, Bacterial Membranes and the Respiratory Chain. New York: Plenum Press.

Heinen, U. J. \& Heinen, W. (1972). Characteristics and properties of a caldoactive bacterium producing extracellular enzymes and two related strains. Archiv für Mikrobiologie 82, 1-23.

Hocking, J. D. \& Harris, J. I. (1973). Purification by affinity chromatography of thermostable glyceraldehyde-3-phosphate-dehydrogenase from Thermus aquaticus. FEBS Letters 34, 280-284.

JACKSON, T. J., Ramaley, R. F. \& Meinschein, W. G. (1973a). Fatty acids of a non-pigmented, thermophilic bacterium similar to Thermus aquaticus. Archiv für Mikrobiologie 88, 127-133.

JaCkson, T. J., Ramaley, R. F. \& MeinsChein, W. B. $(1973 b)$. Thermomicrobium, a new genus of extremely thermophilic bacteria. International Journal of Systematic Bacteriology 23, 28-36.

Ljungdahl, L. G. \& Sherod, D. (1976). Proteins from thermophilic micro-organisms. In Extreme Environments, pp. 147-187. Edited by M.R. Heinrich. New York: Academic Press.

MCFetters, G. A. \& Ulrich, J. T. (1972). Effect of 
temperature on the respiration and cytochromes of an extreme thermophile. Journal of Bacteriology 110, 777-779.

Pask-Hughes, R. \& Williams, R. A. D. (1975). Extremely thermophilic Gram-negative bacteria from hot tap water. Journal of General Microbiology 88, 321-328.

RAy, P. H., White, D. C. \& Brock, T. D. (1971a). Effect of temperature on the fatty acid composition of Thermus aquaticus. Journal of Bacteriology 106, 25-30.

RAy, P. H., White, D. C. \& Brock, T. D. (1971 b). Effect of growth temperature on the lipid composition of Thermus aquaticus. Journal of Bacterio$\log y$ 108, 227-235.

Singleton, R. JR \& AmelunXen, R. E. (1973), Proteins from thermophilic micro-organisms. Bacteriological Reviews 37, 320-342.

SMith, L. (1968). The respiratory chain system of bacteria. In Biological Oxidations, pp. 55-122. Edited by T. P. Singer. New York: Interscience.
TANIGUChI, S. \& Kamen, M. D. (1965). The oxidase system of heterotrophically-grown Rhodospirillum rubrum. Biochimica et biophysica acta 96, 395-428.

VAN GelDER, B. F. (1966). On cytochrome oxidase. I. The extinction coefficients of cytochrome $a$ and cytochrome $a_{3}$. Biochimica et biophysica acta 118, 36-46.

Williams, R. A. D. (1975). Caldoactive and thermophilic bacteria and their thermo-stable proteins. Science Progress 62, 373-393.

Wisdom, C. \& WeLKER, N. E. (1973). Membranes of Bacillus stearothermophilus: factors affecting protoplast stability and thermostability of alkaline phosphatase and NADH oxidase. Journal of Bacteriology 114, 1336-1345.

Zuber, H. (editor) (1976). Enzymes and proteins from thermophilic micro-organisms: structure and function. Experientia, Suppl. 26 